\title{
Emerging trend of Women entrepreneurship in Pakistan
}

\author{
Samina Yaqoob*
}

\begin{abstract}
Though the field of entrepreneurship is continuously growing and mature but still there is a need to explore the role of women entrepreneurship in developing countries. This study highlight, how women execute her entrepreneurial venture while facing different challenges such as cultural, social, and economic constraints etc.? Moreover, how she can play her best role for the welfare of society in developing countries. Our results showed that female entrepreneurial activities herald the optimization of their social and economic wellbeing, moreover it benefits to society through, wealth creation, poverty reduction etc. In this study Gioia methodology was undertaken to explore the women entrepreneur growth route in Pakistan. By the analysis of women personal experience author identified different social, cultural, financial constraints during the growth phase. The new emerging model provide the useful basis for future research imperatives.
\end{abstract}

Keywords: Women Entrepreneurship, Social, Cultural, economic constraints, family support.

This Article can be cited as:

Yaqoob S., (2020). Emerging trend of Women entrepreneurship in Pakistan, Journal of Arts and Social Sciences. VII (2), 217-230.

* Correspondence concerning this article should be addressed to Samina Yaqoob, School of Business and Economics, University of Management \& Technology, Lahore, Pakistan, saminayaqoob130@gmail.com. 


\section{Introduction}

In the world, Entrepreneurship is acknowledged as a fundamental element for economic growth and development (Zaki \& Rashid, 2016; Dvorsky et al., 2018; Meyer \& Synodinos, 2019). Ireland et al., (2001) describe entrepreneurship as a "context-dependent social process through which individuals and teams create wealth by bringing together unique packages of resources to exploit marketplace opportunities" ( $p$. 51). Women owned business are supposed to be fast growing entrepreneurial sector, and it is contributing towards wealth creation, poverty reduction, economic and social growth through innovation, stiffer competition, diversity of business, and utilization of untapped human capital (Brush \& Cooper, 2012; Goltz et al., 2015). Past studies demonstrate that social, cultural, and institutional context of a country effects entrepreneurial activities of women. Culture and tradition form attitude towards working women in a society (Solesvik et al., 2014). Public norms force women to keep socio-cultural in contemplation before starting a traditional job or execution of a new business (Wach, 2015). Women are only restricted to do their work at their home, even though the high qualification holder women are restricted to stitching, boutique, and salon work.

Despite of these social and cultural stresses, women in the developing countries are pushed to start their own business due to domestic needs (Jenning \& Brush, 2013). Women success is highly depending on their family attitudes towards her. Women in such countries turn towards entrepreneurship for better earning, survival, health, and education for their family. For the success of women owned enterprise family members can play a vital role for helping her in household responsibilities, providing her emotional and financial help in the difficult situation. Previously many scholars emphasize the importance of family support (Neneh, 2017; Imbaya, 2012).

Brush and Cooper (2012) state that research work on female entrepreneurship comprise on just 10\% of the whole research studies on the entrepreneurship phenomenon. According to Ahl (2006), research on female entrepreneurship has suffered due to lack of new theoretical grounds. Theory development in the field of entrepreneurship is relatively stagnant, because of the inability to come up with new ideas. This may be endorsed to the preference of the scholars to design and execute theory development by using positivist research philosophy (Gioia et al., 2013). But it is not possible to develop a new theory by using traditional positivistic approach so in this study we use interpretive research philosophy. This study addresses the following questions: how does women execute her entrepreneurial venture while facing different challenges such as cultural, social, economic constraints etc.? Moreover, how women can play her best role for the welfare of society in developing countries? To address these questions, we set out to understand what factors compels women to become an entrepreneur in the first place. How social, cultural, family, and institutional factors support or hinder growth of female business ventures? And how different individual characteristics and perceptual factors work in aggregation to produce a successful women entrepreneur. Due to modernization and financial crises, the overall attitude has been changing and women are consider helping hand with the man because a single person cannot fulfil whole family financial needs. For the success of women owned enterprise the family support can play a critical role (Neneh, 2017; Imbaya, 2012).

\section{Literature review}

Lazear (2005) Entrepreneurship as "the process of assembling necessary factors of production consisting of physical ,human and knowledge assets and doing so in an effective way" and entrepreneurs as those who "put people together in specific manners and combine them with physical capital and ideas to generate a new invention or to produce new product. Women entrepreneur can be defined as "a confident, innovative and creative women capable of achieving self-economic independence individually or in collaboration, generates employment opportunities for others though initiating, establishing and running the enterprise by keeping pace with her personal family and social life"(Ganesamurthy, 2007). Women of developing countries are much aware about their rights and they can get the respectable position in the society by launching their own business activities and can serve better to their families and 
benefits to society by poverty reduction, generation of employment opportunities and acting as role model for others women as well. As literature evidenced that women much aware about their rights ,their existence, and their job condition due to the rising urbanization, industrialization, and social law and increasing opportunities of higher education and awareness, the occurrence of females owned industries are rapidly boosting in the economies of globally (Bulsara et al, 2014). Presently, the number of selfemployed females is steadily increasing, but most female-owned enterprises are still functioning in small sectors (Marlow \& McAdam, 2013). These sectors demonstrate low progress in productivity and market share. Women owned business initiatives grow at a slowly than their male counterparts (Morris et al., 2006). This is because women entrepreneurs face problems such as management practice, entrepreneurial policies, financing, growth strategies and entrepreneurial policies (Noguera et al., 2015). Existing literature on female entrepreneurship focuses on individual, social and institutional factors (Pérez-Pérez \& Avilés-Hernández, 2016). However, individual factors alone are not sufficient to fully describe entrepreneurship (Shane \& Venkataraman, 2000). But contextual factors are also critical for the execution of women entrepreneurial venture.

Pakistan is developing country and here is masculine hegemony is dominated as compared to women. Women have no freedom to take their decision related to everyday life sphere. Society believes that males are responsible for financially supporting their families while women are charged with caring for family, children, and other dependents. This role segregation states that man is role model to execute and run a business (Nicolás \& Rubio, 2016). This is supported by the fact that entrepreneurship studies are subject by masculine features (Al-Dajani \& Marlow, 2013). The man dominated and patriarchal philosophies have always considered women to be inferior to man (Foss et al., 2013) which prevent the contribution of female in business actions. Thus, number of business startups by women noticeably behind as compare to male (Minniti \& Nardone, 2007).In Pakistan, the female entrepreneurs are not getting same opportunities as available to male entrepreneurs due to biased social and cultural values which are deeply rooted into cultural values (Roomi \& Parrot, 2008). Due to greater gender inequality, there is negligible numbers of female entrepreneurial activities in Pakistan. Pakistani females suffer with lack of assistance in starting venture, access to capital, land and other resources, training, and development facilities due to the male dominated society.

According to trading economic and index-mundi (2020) report overall expected un- employment rate is $6 \%$ that from 2020 to 2021. (Trading economics global macro model, 2020, accessed 21 September 2020). Due to this high number of jobless people there is high demand that the people will start their own venture or go towards entrepreneurship.

\section{Methodology}

This study uses interpretive paradigm and employs Gioia Methodology proposed by Gioia, and his colleagues (2013). Gioia methodology is specifically suitable to study women entrepreneurs as several researchers believe that entrepreneurship is social and contextual phenomenon (Brush et al., 2009). This study based on purposeful sampling method in selecting informants. This sampling technique is used by Nag \& Gioia (2012) in their attempt to comprehend how managers can attain strategic benefit through unusual use of knowledge.

\section{Interview protocol}

The female informants are identified and contact through personal networks. Based on literature review open ended questionnaire for interview were designed by the researcher. By employing the recommendations of Gioia, Corley \& Hamilton (2013), data collection have been done after two weeks of taking the appointment for an interview. High importance is given to the interview protocol so that the informants may feel comfortable with the researcher and explain everything in detail related to study objectives. Over the period of 3 week the interview was conducted on women's homes. For getting the detailed information from the informants a semi structure interview was conducted. Researcher did try to 
limit the informants account by using preconceived assumption. Women's have explained all things by sharing their own experience. They describe their feelings, emotions, and experiences openly. Researchers take field notes during the interview that is immediately transcribed after the interview.

\section{Data analysis}

In this research study author used the Gioia et al (2013), content analysis strategy. By utilizing this strategy develop first order code, then second order, and following the aggregate dimension.

\section{Interview Transcribing}

The conducted interview is transcribed in the English language. When the whole transcription process completed, and the key findings clarified then it will give a clear picture about different phenomenon such as motivation behind this entrepreneurial set up. It also provides an outlook that we have to review and reexamine the interview questions where we are not clear about things or where we feel that the answer is too short or inappropriate. First-Order Code: By following the Gioia et al (2013) methodology the first order coding process completed. During this process researcher analyze each response of interviewee, in terms of motivational force behind entrepreneurship and specific context. The process is started by reading out the interview transcripts, then followed by listening, then recording of interview, with the help of past literature, develop the first order code for this study. Researcher also visualize the verbal response of interviewee during the interview secession and try to get the dipper meaning and feeling on each response. Researcher evaluated each response against a particular question by the interviewee from the development of first order code and also included the literature for better understanding of the phenomenon, then check the similarities and differences among each other. Secondorder code: After the completion of first order code we moved toward second order coding by reviewing the existing literature. Interpretation of data has been done with the help of past literature. After the collection of first order code combination, researcher classified them into themes and then from these themes get the more abstract level results that is called second-order codes (Strauss \& Corbin, 1998). Then second order code are classified as motivational forces, context, and exploitative verses explorative. Aggregate dimensions: This is last step, in this phase all the themes are reevaluated with the help of relevant literature and researcher also review the interview transcripts again to find additional confirmation in support of each themes (Gioia et al., 2013). Then the themes are organized and get more abstract level results, that is called aggregate dimension.

\section{Research findings}

In this part we first explain the geographic context in which female designers motivate to start a business venture why, how, and when they start entrepreneurship (Welter, 2011). This study is conducted in lower Punjab of Pakistan. This interview illustrate that informants formally started their work approximately at the age of 20 to 22 years, now they have 7 years of professional experience in fashion designing (only focus on women wear) .For assurance of objectivity the table. 2 present the finding in non-interpretive way a presented by interviewees. To ensure the legitimacy of analysis, author has structured the finding by employing the Gioia methodology (Gioia et al., 2013).

\section{Demographics about women's entrepreneurs}

The background information about female entrepreneur is elaborated in table below. From this background information we can get a clear picture about why, how and when women's moves towards entrepreneurship. As Welter (2011) emphasize that context is more important when considering entrepreneurship phenomenon why, how, when they started their venture. Albeit we move back and forth to review literature and the interview transcripts these information give us a chance to overview about the entrepreneur's background (entrepreneur's age, marital status, education level, entrepreneur's choices, and professional experience). 
Table 1. Demographic of Females entrepreneurs

\begin{tabular}{l|l}
\hline Interviewee & Female \\
\hline Age & 25 to 27 years \\
\hline Marital Status & Married \\
\hline Education level & Bachelor \& Master \\
\hline Relevant industry & Fashion designer (women wear) \\
\hline Entrepreneurial experience & 5 to 7 years \\
\hline
\end{tabular}

\section{Motivational factors}

For the success in life the personal motivation does matter a lot, so in this research work first researcher described the motivational factors that are key source to become an entrepreneur. In our case of female's entrepreneurs basically an opportunity driven entrepreneur to turn into social driven entrepreneur. In the past scholars explore variety of reasons for female to become entrepreneurs (Itani et al, 2011). Some of these reasons are represented below in table. 2

Table 2. Emerging Themes and representatives' quotations

\begin{tabular}{|c|c|}
\hline Emerging Themes & Representative Quotations \\
\hline \multicolumn{2}{|c|}{ Motivational factors behind entrepreneur } \\
\hline Social and cultural problems & $\begin{array}{l}\text { - "My father was against me because he does not like that, I go to } \\
\text { market this may be due to our cultural barrier (what people say } \\
\text { about my daughter etc.) But my brother and especially my } \\
\text { mother provide me greatest support for this business startup"." } \\
\text { (Women Entrepreneur) }\end{array}$ \\
\hline Economic issues: opportunity driven & $\begin{array}{l}\text { - "My family is financially stable and I collected my monthly } \\
\text { pocket money during my graduation and spent those money on } \\
\text { my crafts and designing and my brother has provided me with } \\
\text { the capital and supported me in all financial matters." (Women } \\
\text { Entrepreneur) }\end{array}$ \\
\hline Encouragement: family support & $\begin{array}{l}\text { - "My work is much appreciated by my family members and } \\
\text { cousins. They follow my designing and they used to take my } \\
\text { suggestions and sometimes give me a responsibility to design } \\
\text { dresses for them on Eid festivals and on marriage ceremonies." } \\
\text { (Women entrepreneur). } \\
\text { "My uncle never admires easily others work but, in my case, he } \\
\text { admires openly that my dress taste is very good "." (Women } \\
\text { Entrepreneur) }\end{array}$ \\
\hline Becoming own boss & $\begin{array}{l}\text { - I think running own business gives you self-confidence and } \\
\text { demanding hardworking and your commitments as well.it } \\
\text { empower you because no one is your boss. your boss is your } \\
\text { own passion". (Women Entrepreneur) }\end{array}$ \\
\hline \multicolumn{2}{|c|}{ Challenges faced during start up business } \\
\hline Social: Family issue & $\begin{array}{l}\text { - "My father offended me, why I go to Market and spend time in such } \\
\text { a useless activity. According to my father I waste my time, I should } \\
\text { focus on my study. But it could not stop my passion" (Women } \\
\text { Entrepreneur) }\end{array}$ \\
\hline
\end{tabular}




\begin{tabular}{|c|c|}
\hline $\begin{array}{l}\text { Geographical location: } \\
\text { Underdeveloped city (low } \\
\text { profitability" }\end{array}$ & $\begin{array}{l}\text { - Financial risk is more involved than others. I face many problems } \\
\text { most of the time customer bargain and there is need to give the } \\
\text { awareness to the customer that they can get a stylish dress in less } \\
\text { amount. (Women Entrepreneur) }\end{array}$ \\
\hline Limited Technological advancement & $\begin{array}{l}\text { Social media can be powerful tool to attract and capture old and } \\
\text { new customer. In my case I only used what's app group to } \\
\text { advertise my product and this group is only consists of my } \\
\text { colleagues, friends, and friends of friends. I also made } \\
\text { Facebook page for my product advertisement. Social media can } \\
\text { boost your business (Women Entrepreneur) }\end{array}$ \\
\hline \multicolumn{2}{|c|}{ Supporting Factors for growth of women owned enterprises } \\
\hline $\begin{array}{l}\text { Individual characteristics of } \\
\text { entrepreneur - Inborn quality of } \\
\text { creativity }\end{array}$ & $\begin{array}{l}\text { - "I love to play with colours from my childhood. I was very good in } \\
\text { drawing\& sketches as well and make unique drawing with } \\
\text { innovative colour schemes, which was admired by my family } \\
\text { members, teachers, and class fellows. At that stage I feel it a biggest } \\
\text { achievement of my life." (Women Entrepreneur) }\end{array}$ \\
\hline $\begin{array}{l}\text { Individual characteristics of } \\
\text { entrepreneur cultural/religious } \\
\text { values consideration }\end{array}$ & $\begin{array}{l}\text { - "I always follow cultural and traditional values, Whenever I go to } \\
\text { market, I properly cover myself, and people treat me with respect." } \\
\text { (Women Entrepreneur) }\end{array}$ \\
\hline Social context - support. & $\begin{array}{l}\text { - My husband supported me a lot. Without his support, I would not } \\
\text { be able to achieve all this. My brothers and mother are also very } \\
\text { supportive. In the absence of my husband, brothers used to help me } \\
\text { in advertising my products. (Women Entrepreneur) } \\
\text { - }\end{array}$ \\
\hline $\begin{array}{l}\text { Social context - Changing behavior } \\
\text { (innovation) }\end{array}$ & $\begin{array}{l}\text { - I focused on my product, I made my product (dresses) in such a } \\
\text { unique way that it appeals to customer and the buyer will never go } \\
\text { without buying my designed dresses. Most of the time I prepare } \\
\text { dress before two, three days of final delivery date." (Women } \\
\text { Entrepreneur) } \\
\text { - "My tailor and karighar is so much trained that I just one time tell } \\
\text { them my idea then they prepared the whole dress according to my } \\
\text { estimation. I also take their suggestion before sketching and } \\
\text { appreciate their suggestions and ideas." (Women Entrepreneur) }\end{array}$ \\
\hline \multicolumn{2}{|l|}{ Society benefits } \\
\hline Strong social capital & $\begin{array}{l}\text { - I only focus on my social circle and made dresses for } \\
\text { my family friends and friends of friends but in future I } \\
\text { have plan to participate in exhibition of different } \\
\text { colleges, school and universities." (Women } \\
\text { Entrepreneur) } \\
\text { I also made dresses for my husband office colleagues } \\
\text { (Dubai), they inspired by my creativity and designing, } \\
\text { when my husband come to Pakistan then they order } \\
\text { their dresses and I prepared their dresses with zest and } \\
\text { zeal. Now my husband colleagues became my } \\
\text { permanent customer they further spread my fame } \\
\text { through words of mouth to their friends and they also } \\
\text { order their friend dresses as well." (Women } \\
\text { Entrepreneur) }\end{array}$ \\
\hline
\end{tabular}




\begin{tabular}{l|c}
\hline Value creation for society & \begin{tabular}{l} 
- $\begin{array}{l}\text { I started it as my hobby, when I saw that my social } \\
\text { circle network admired my creativity in designing. I } \\
\text { thought, it must do something for others as well." } \\
\text { (Women Entrepreneur) }\end{array}$ \\
\hline \multicolumn{1}{c|}{ Continuous learning } \\
\hline Individual: power of knowledge
\end{tabular}$\quad \begin{array}{l}\text { "I am not following any formal business education but in future } \\
\text { I have plan to register in PM E.Rozghar programme. } \\
\text { Master in English literature give me power of communication, } \\
\text { further I know more about the human zouq and taste, now I can } \\
\text { communicate very well with every type of customer." (Women } \\
\text { Entrepreneur) }\end{array}$ \\
\hline
\end{tabular}

Social and cultural issues: Pakistan is a developing country and here is masculine hegemony and male dominated social structure. Therefore, females find little opportunities to start her own business. Women have no independence of decision in their life, need the approval from their men to do something. A study conducted by Calas, Smircich, and Bourne (2009) they elaborated that female have to face many challenges in masculine hegemony and male dominate society.in this society women feel comfortable to work at home such as stitching, salon work or run a boutique. Economic issues: In developing countries women enter entrepreneurship for the fulfillment of her financial needs. So, most of the time necessity driven women entrepreneurship emerges. In literature majority studies are in favor of necessity driven entrepreneurship (e.g. Ahl \& Nelson, 2015). Women start her own business to gain the self-confidence and fulfil the financial needs of her and other family members. But in this study of interviewee state my passion is more important at that stage of my life and she start her work as a hobby and turning it into business. Encouragement from Family members: Neneh (2017) identified that family support in the form of instrumental, emotional, and financial is positively linked to the success of women entrepreneurs. Imbaya (2012) said that families of women entrepreneur should be supportive in her household responsibilities and in other financial matter so that women should full exploit her potential to achieve the growth. In Masculine society female find no support from their families but now the trend has changing. Society attitude towards women role has changing with the passage of time in Pakistan. Becoming own Boss: Byrne et al (2019) suggested that women's "strong interest" and "passion" can derive new business venture in entrepreneurship. Women is a boss of her own and have a full power to do anything according to her own will. The aspiration to become entrepreneur is driven by desire for personal accomplishment and achievement and economic benefits may become less pertinent for women entrepreneurs (Itani et al, 2009). Independence, control and becoming one's own boss is often cited factor among women entrepreneurs (Fatoki, 2010). Entrepreneurship is described as discovery, evaluation, exploitation, and pursuit of an economic opportunity.

\section{Challenges}

A female entrepreneur face different challenges during the early stage of her business. Such as family issues, Financial constraints (low profitability), by heart no entrepreneurial attitude, Geographical location (Underdeveloped city) and Technological constraints (limited level usage. Social: Family issue: Parents play vital role for the upbringing of their children. As Neneh (2017) identified that family support in the form of instrumental, emotional, and financial is positively linked to the success of women entrepreneurs. Support from close relative and family members acts as motivator for female entrepreneur (Fatoki, 2010).But in case of Pakistan, we have restricted our females at home, generally men did not provide freedom to women that she works outside of home. These values, beliefs are deeply rooted in the Pakistani society culture. Moreover, female entrepreneurs experience more conflicts as compare to males, due to societal beliefs and expectation from females, consequently effects on women investment decisions (Bat1 \& Armutlulu, 2020). Geographical location, underdeveloped city: Recently Meyer and Hamilton (2020) stated that in developing countries women's get less education and training as compared to men. 
Additionally, in under develop city customers have less awareness. As our female interviewee expressed that customer from backward city are not ready to pay you according to your estimation. They have not known about the importance of designer dresses, maybe they have low purchasing power, or they have low attitude towards purchasing. Limited Technological advancement: Rise of Social media brings tremendous changed in the entrepreneur's everyday business activities (Olanrewaju et al, 2020). Social media is a movement from 'static' sites towards more shared, intelligent, and responsive web composition. Currently entrepreneurs used Social media as a tool for business networking, crowdfunding, and getting updated information for the promotion of their business (Olanrewaju et al, 2020).Social media with low cost and required low skills creates great business value for entrepreneurs (Nakara et al, 2012; Stockdale et al, 2012).It empowers communications to cross at least one stages or administrations through sharing connections and includes diverse levels of engagement by members who can read, react to and republish tremendous amounts of data unreservedly and effectively. Online networking members are shoppers of data who carry on in new ways, repurposing and sharing information as half and half makers and clients, independently and progressively in gatherings. A decent case is 'Inventive Commons' authorizing through which people sidestep built up copyright laws by making their work accessible for nothing non-business uses (Gibson et al., 2009; Shirky, 2009).

\section{Supporting Factors for growth of women owned enterprises}

Individual characteristics of entrepreneur - inborn quality of creativity: One of our informants said that she has inborn quality of creativity. Every time she has a desire to look different from others. Entrepreneurship is related with the personality traits that make someone different and unique with others. Cultural/religious values consideration: The importance of ethical consideration in the Islamic society is supreme. Isl amic values call for both men and women to detect a code of ethics while conducting daily routine activities. Though, Islam has charged male to be accountable for satisfying financial obligations of wife and their kids, however, it gives a certain degree of autonomy to females in conducting their own financial deeds.Family support: As Nehen (2017) notified that support from family in the form of economical, emotional or instrumental have a positive association with the success of women entrepreneur. Apart from material resources, family is used to emotional support through advice, encouragement, guidance etc., which in turns provide emotional stability and enhances physiological capital of entrepreneur (Arregle et al., 2015). Family provide support in tough time of women entrepreneur venture. Imbaya (2012) informed that family members of, women entrepreneur should help her in her household responsibilities and other financial matter in order to exploit the opportunities with her full potential. Support from close relative and family members acts as motivator for female entrepreneur (Fatoki, 2010). Innovative behavior: Our interviewee said that she follows tradition and rituals and follow her own idea. Yulisetiarini (2013) said, "Customer is a king" means that they should be served well. Our entrepreneur kept in mind, accuracy, value for money, consistency, customization/personalization, courtesy while deliver her product to the customer.

\section{Continuous Learning and Societal benefits}

Continuous learning: Continuous learning can give you sustained competitive advantage over your competitors as blue ocean companies (e.g. APPLE) they are continuously learning from their environment and follow sensing, seizing and exploitation. As entrepreneur ready to take the risks and follow all these steps. The organization that stop learning then there is knowledge Ossification occurs in that organization. Strong social capital: Women of underdeveloped countries mostly work in traditional household crafts industries, and they depend on these social ties. In these countries, women use their informal networks involving mainly of their extended family, friends, and neighbors. These social connections give access to key resources such as human capital, information, finance, etc. Women entrepreneurs are supposed to be crucial for rising a prosperous society (Hoyt \& Murphy, 2016). Value creation for society: Women entrepreneur create the value for society by providing her innovative and creative services and product to 
the community. By providing them awareness about the designer outfit, how you look different from others with less price.

\section{Emerging new model}

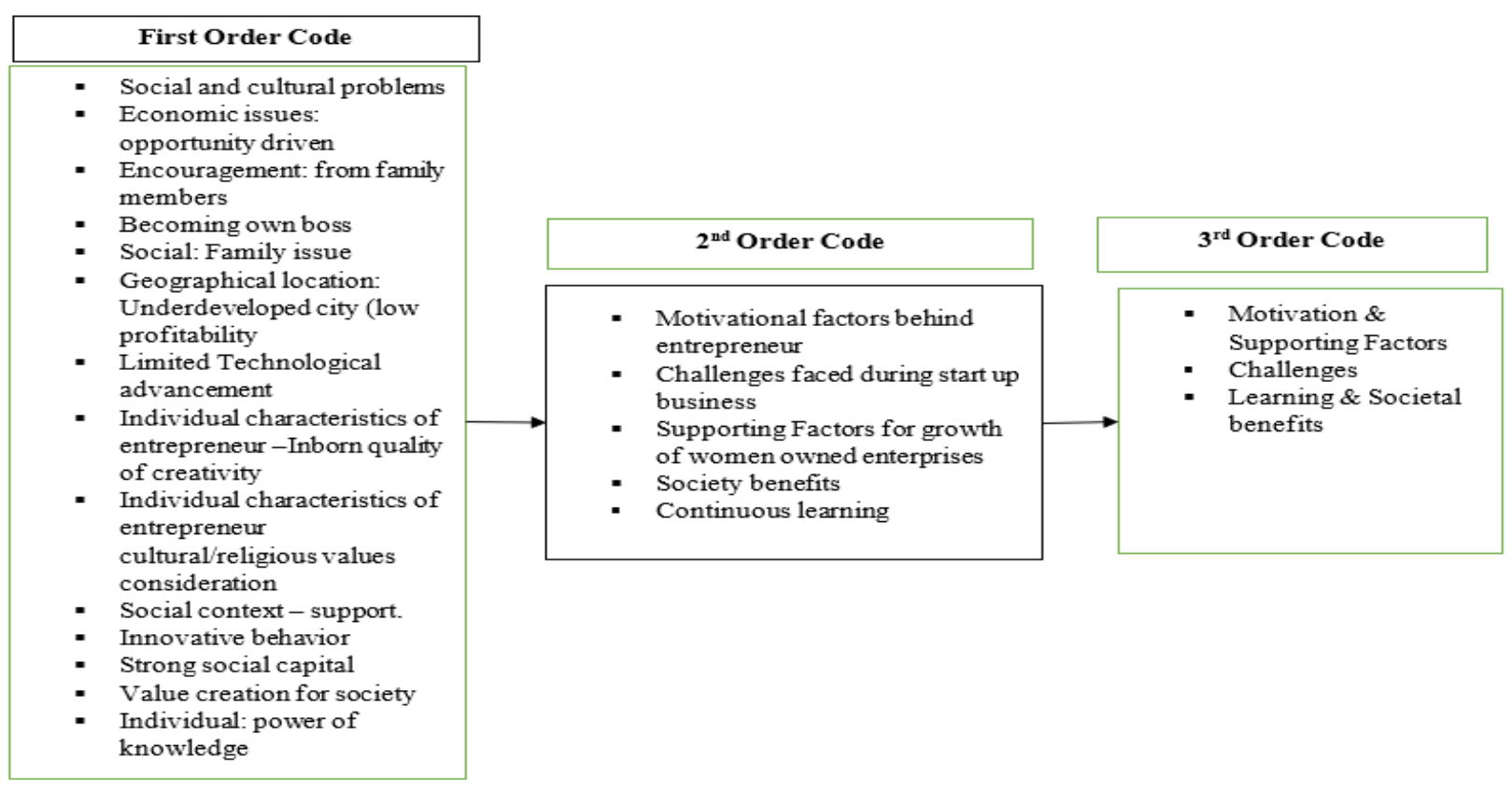

Figure.1 Emerging model

\section{Discussion}

In the past many research studies conducted in the field of entrepreneurships in the economic and social/cultural perspectives but the difficulties, challenges women entrepreneur phase during her business startup and growth remain an under explored area. This study try to fill this gap by addressing the role of economic, social, cultural and technological aspects for the creation of women entrepreneurial venture in the developing country like Pakistan.it state that how a female entrepreneur progress from financial deprived women to more powerful, independent entrepreneur. In Pakistan there is masculine class is more dominant as compare to females. Women have no full freedom to decide her life matters independently. Due to monetary and financial constraints, women are unable to satisfy their basic needs. They are left with very few career choices. A study conducted by Calas, Smircich, and Bourne (2009) they elaborated that female must face may challenges in masculine hegemony and male dominate society. Secondly this research work contributes by carry out an inductive process model that have a linked with different social, economic and cultural dimensions. Further it states that not only necessity driven women entrepreneur emerges but someone passion, craze, hobby may be a source to become an entrepreneur. That not only serve her family independently but also create a value in society.

There are many factors that inhibit the growth of women owned enterprise such as financial constraints, family, caste, and cultural issues etc. in necessity driven entrepreneurship women takes risk and try to fulfill the financial needs of her family, children. But in this study we find opposite that our women move motivate towards entrepreneurship due to her social capital and she enters in this business because she sense opportunities in the environment and try to synthesize these information and plan for 
exploiting these opportunities. In this research study our interviewee give high impotence to customer satisfaction and try to provide best services to their customer because she knows well that customer is the king, she should customize her product according to the customer personality traits and consumer purchasing power. This study also enlightens the importance of social capital for the growth and profitability of your business. Your social ties can be your best assets for the success of entrepreneurial venture. Moreover, the continuous learning can lead to successful entrepreneurial endeavor.

This study contributes in the literature by addressing the entrepreneurial motivation especially emerging women entrepreneur. This study also enforces the contextual factors how, when, and why entrepreneurs emerges (Walter et al. 2011). It enlightens the women entrepreneurial role from financial deprived to transform into sound, stable financial condition. Now she can not only up bring their children but also become a role model for other women in Pakistan. This study shows that not only contextual, cultural, economic challenges impact for the creations of successful business enterprise but human personal traits, creativity, passion, self-determination, self-actualization may also cause for the advancement towards the entrepreneurship. It is qualitative paradigm-based research work. The emerging theory developed in this paper is highly contextual bound and it may have limited generalization. Future researcher may test these findings for the empirical validity of emerging model.

\section{Conclusion}

This study discussed the cultural, social, economic/ financial, and contextual challenges that an emerging women entrepreneur have to face during the start and growth of her business. Further highlight the different problems that she must overcome for the execution of business endeavors in Pakistan. Author unanimously confirmed that women entrepreneur creates the value for herself in the form of independence and financially sound position and for the society in the form of poverty alleviation and generate the employment opportunities for young graduates. She also acts as a role model for others who are unemployed, they may serve themselves through taking the entrepreneurial initiatives. Although women entrepreneur need the support from her family members, who support her in managing the household work and provide her morally, financially support so that she will utilize her maximum potential for the exploitation of business opportunities otherwise she will suffering mentally and physically by work life conflict. Women informants enforce on the human personal trait that will be the triggering factors to startup entrepreneurship other than economic and contextual factors. If someone have the quality of selfactualization, commitment and hardworking and also continuously learn then he/she will exploit the business opportunities and can execute a successful business activity.

\section{References}

Ahl, H. (2006). Why research on women entrepreneurs needs new directions. Entrepreneurship theory and practice, 30(5), 595-621.

Ahl, H., \& Nelson, T. (2015). How policy positions women entrepreneurs: A comparative analysis of state discourse in Sweden and the United States. Journal of Business Venturing, 30(2), 273-291.

Al-Dajani, H., \& Marlow, S. (2013). Empowerment and entrepreneurship: A theoretical framework. International Journal of Entrepreneurial Behaviour \& Research, 19(5), 503-524.

Arregle, J. L., Batjargal, B., Hitt, M. A., Webb, J. W., Miller, T., \& Tsui, A. S. (2015). Family ties in entrepreneurs' social networks and new venture growth. Entrepreneurship Theory and Practice, 39(2), 313-344.

Brush, C. G., \& Cooper, S. Y. (2012). Female entrepreneurship and economic development: An 
international perspective. Entrepreneurship \& Regional Development, 24(1-2), 1-6.

Brush, C. G., De Bruin, A., \& Welter, F. (2009). A gender-aware framework for women's entrepreneurship. International Journal of Gender and entrepreneurship, 1(1), 8-24.

Bulsara, H. P. B., Chandwani, J., \& Gandhi, S. B. (2014). Women entrepreneurship and innovations in India: an exploratory study.

Byrne, J., Fattoum, S., \& Diaz Garcia, M. C. (2019). Role models and women entrepreneurs: Entrepreneurial superwoman has her say. Journal of Small Business Management, 57(1), 154-184.

Calas, M. B., Smircich, L., \& Bourne, K. A. (2009). Extending the boundaries: Reframing "entrepreneurship as social change" through feminist perspectives. Academy of Management Review, 34(3), 552-569.

De Vita, L., Mari, M., \& Poggesi, S. (2013). Female entrepreneurship research: a classification of results. Essays in Management, Economics \& Ethics, (26).

Díaz, F. J., Venosa, P., Macia, N., Lanfranco, E. F., Sabolansky, A. J., \& Rubio, D. (2016, June). Análisis digital forense utilizando herramientas de software libre. In XVIII Workshop de Investigadores en Ciencias de la Computación (WICC 2016, Entre Ríos, Argentina).

Dvorsky, J., Popp, J., Virglerova, Z., Kovács, S., \& Oláh, J. (2018). Assessing the importance of market risk and its sources in the SME of the Visegrad Group and Serbia. Advances in Decision Sciences, 22, 1-22.

Fatoki, O. O. (2010). Graduate entrepreneurial intention in South Africa: motivations and obstacles. International Journal of Business and Management, 5(9), 87.

Foss, L., Woll, K., \& Moilanen, M. (2013). Creativity and implementations of new ideas: do organisational structure, work environment and gender matter?. International Journal of Gender and Entrepreneurship, 5(3), 298-322.

Ganesamoorthy, C., Balakrishna, M. S., George, P. P., \& Mague, J. T. (2007). Di-and Tetranuclear Copper (I) Complexes Containing Phenylaminobis (phosphonite), $\mathrm{PhN}\{\mathrm{P}(\mathrm{OC} 6 \mathrm{H} 4 \mathrm{OMe}-\mathrm{o}) 2\} 2$, and Their Reactivity toward Bipyridyl Ligands. Inorganic chemistry, 46(3), 848-858.

Ganesamurthy, V. S. (2007). India: economic empowerment of women. New Century Pubns.

Gibson, T. J., Johnson, C. B., Murrell, J. C., Chambers, J. P., Stafford, K. J., \& Mellor, D. J. (2009). Components of electroencephalographic responses to slaughter in halothane-anaesthetised calves: Effects of cutting neck tissues compared with major blood vessels. New Zealand Veterinary Journal, 57 (2), 84-89. 
Gioia, D. A., Corley, K. G., \& Hamilton, A. L. (2013). Seeking qualitative rigor in inductive research: Notes on the Gioia methodology. Organizational research methods, 16 (1), 15-31.

Goltz, S., Buche, M. W., \& Pathak, S. (2015). Political empowerment, rule of law, and women's entry into entrepreneurship. Journal of Small Business Management, 53(3), 605-626.

Grosman, K., \& Wilmink, F. (2017). Contextualizing entrepreneurship: Getting to know the elderly entrepreneur who started out of unemployment.

Bulsara, H. P. B., Chandwani, J., \& Gandhi, S. B. (2014). Women entrepreneurship and innovations in India: an exploratory study.

Hitt, M. A., Ireland, R. D., Camp, S. M., \& Sexton, D. L. (2001). Strategic entrepreneurship: Entrepreneurial strategies for wealth creation. Strategic management journal, 22(6-7), 479-491.

Hoyt, C. L., \& Murphy, S. E. (2016). Managing to clear the air: Stereotype threat, women, and leadership. The Leadership Quarterly, 27(3), 387-399.

Imbaya, B. H. O. (2012). The role of family support in performance of women-operated micro and small enteprises in Eldoret, Kenya. Journal of Emerging trends in economics and management sciences, 3(5), 502.

Ireland, R. D., Hitt, M. A., Camp, S. M., \& Sexton, D. L. (2001). Integrating entrepreneurship and strategic management actions to create firm wealth. Academy of Management Perspectives, 15(1), 49-63.

Itani, H., Sidani, Y. M., \& Baalbaki, I. (2011). United Arab Emirates female entrepreneurs: motivations and frustrations. Equality, Diversity and Inclusion: An International Journal, 30(5), 409-424.

Jennings, J. E., \& Brush, C. G. (2013). Research on women entrepreneurs: challenges to (and from) the broader entrepreneurship literature?. The Academy of Management Annals, 7(1), 663-715.

Kilkenny, M., \& Fuller-Love, N. (2014). Network analysis and business networks. International Journal of Entrepreneurship and Small Business 15, 21(3), 303-316.

Lazear, E. P. (2005). Leaders and entrepreneurs: where they produce the most value. In Allied Social Science Associations Annual General Meeting, Philadelphia.

Marlow, S., \& McAdam, M. (2013). Gender and entrepreneurship: Advancing debate and challenging myths; exploring the mystery of the under-performing female entrepreneur. International Journal of Entrepreneurial Behavior \& Research, 19(1), 114-124.

Meyer, N. (2019). South African female entrepreneurs' business styles and their influence on various entrepreneurial factors. In Forum Scientiae Oeconomia (Vol. 7, No. 2, pp. 25-35). Wydawnictwo 
Naukowe Akademii WSB.

Minniti, M., \& Nardone, C. (2007). Being in someone else's shoes: the role of gender in nascent entrepreneurship. Small Business Economics, 28(2-3), 223-238.

Morris, M. H. (2015). Entrepreneurship as experience. Wiley Encyclopedia of Management, 1-6.

Morris, R. V., Klingelhoefer, G., Schröder, C., Rodionov, D. S., Yen, A., Ming, D. W., ... \& Bernhardt, B. (2006). Mössbauer mineralogy of rock, soil, and dust at Meridiani Planum, Mars: Opportunity's journey across sulfate-rich outcrop, basaltic sand and dust, and hematite lag deposits. Journal of Geophysical Research: Planets, 111(E12).

Nag, R., \& Gioia, D. A. (2012). From common to uncommon knowledge: Foundations of firm-specific use of knowledge as a resource. Academy of Management Journal, 55(2), 421-457.

Neneh, B. N. (2017). Family Support and Performance of Women-owned Enterprises: The Mediating Effect of Family-to-Work Enrichment. The Journal of Entrepreneurship, 26(2), 196-219.

Nicolás, C., \& Rubio, A. (2016). Social enterprise: Gender gap and economic development. European journal of management and business economics, 25(2), 56-62.

Noguera, M., Alvarez, C., Merigo, J. M., \& Urbano, D. (2015). Determinants of female entrepreneurship in Spain: an institutional approach. Computational and Mathematical Organization Theory, 21(4), 341-355.

Olanrewaju, A. S. T., Hossain, M. A., Whiteside, N., \& Mercieca, P. (2020). Social media and entrepreneurship research: A literature review. International Journal of Information Management, 50, 90-110.

Pérez-Pérez, C., \& Avilés-Hernández, M. (2016). Explanatory factors of female entrepreneurship and limiting elements. Suma de Negocios, 7(15), 25-31.

Roomi, M. A., \& Parrott, G. (2008). Barriers to development and progression of women entrepreneurs in Pakistan. The Journal of Entrepreneurship, 17(1), 59-72.

Shane, S., \& Venkataraman, S. (2000). The promise of entrepreneurship as a field of research. Academy of management review, 25(1), 217-226.

Shirky, C. (2009). Here comes everybody: How change happens when people come together. Penguin UK.

Solesvik, M., Westhead, P., \& Matlay, H. (2014). Cultural factors and entrepreneurial intention: The role of entrepreneurship education. Education + Training, 56(8/9), 680-696.

Stockdale, R., Ahmed, A., \& Scheepers, H. (2012). Identifying Business Value From The Use Of Social Media: An Sme Perspective. In PACIS (p. 169). 
Strauss, A., \& Corbin, J. (1998). Basics of qualitative research: Procedures and techniques for developing grounded theory.

Trading Economics, (2020).Pakistan Unemployment Persons.(online available): https://tradingeconomics.com/pakistan/unemployed-persons

Wach, K. (2015). Entrepreneurial orientation and business internationalisation process: The theoretical foundations of international entrepreneurship. Entrepreneurial Business and Economics Review, 3(2), 9-24.

Welter, F. (2011). Contextualizing entrepreneurship — conceptual challenges and ways forward. Entrepreneurship theory and Practice, 35(1), 165-184.

Yulisetiarini, D. (2013). The Role of Service, Price, Promotion, Place, And Comfort On Customer Satisfaction And Switching Intention In Minimarket At Jember Regency.

Zaki, I. M., \& Rashid, N. H. (2016). Entrepreneurship impact on economic growth in emerging countries. The Business \& Management Review, 7(2), 31. 